\title{
Reliability of the MOCART score: a systematic review
}

\author{
Filippo Migliorini ${ }^{1 *} \mathbb{B}$, Nicola Maffulli ${ }^{2,3,4}$, Jörg Eschweiler ${ }^{1}$, Arne Driessen ${ }^{1}$, Markus Tingart ${ }^{1}$ and Alice Baroncini ${ }^{1}$
}

\begin{abstract}
Background: The present systematic review analysed the available literature to assess reliability of the Magnetic Resonance Observation of Cartilage Repair Tissue (MOCART) score in the evaluation of knee and ankle osteochondral lesions.

Methods: All the studies using the MOCART score for knee and/or talus chondral defects were accessed in March 2021. A multivariate analysis was performed to assess associations between the MOCART score at last follow-up and data of patients at baseline, clinical scores and complications. A multiple linear model regression analysis was used.

Results: The MOCART score evidenced no association with patient age $(P=0.6)$, sex $(P=0.1)$, body mass index $(P=0.06)$, defect size $(P=0.9)$, prior length of symptoms $(P=0.9)$ or visual analogue scale $(P=0.07)$. For chondral defects of the knee, no statistically significant association was found between the MOCART score and the International Knee Documentation Committee $(P=0.9)$ and with the Lysholm Knee Scoring Scales $(P=0.2)$, Tegner Activity Scale $(P=0.2)$, visual analogue scale $P=0.07)$, rate of failure $(P=0.2)$ and revision $(P=0.9)$. For chondral defect of the talus, no statistically significant associations were found between the MOCART score and the American Orthopedic Foot and Ankle Score $(P=0.3)$, Tegner Activity Scale $(P=0.4)$, visual analogue scale $(P=0.1)$, rate of failure $(P=0.1)$ and revision $(P=0.7)$.
\end{abstract}

Conclusion: The MOCART score demonstrated no association with patient characteristics and with the surgical outcome in patients who underwent surgical management for knee and talus chondral defects.

Level of evidence: Level IV.

Keywords: Chondral defect, Knee, Talus, MOCART

\section{Introduction}

Acute injuries, repeated strains or joint instability can produce osteochondral lesions (OL), with damage to the hyaline cartilage of the joint and to the subchondral bone [1,2]. Typically, these lesions lead to a decrease in daily activities from pain on weight bearing and exercise [3]. Several surgical techniques are available for the operative management of OL of the knee and ankle: it necessary to have reliable evaluation tools to compare the outcomes of the different techniques

\footnotetext{
${ }^{*}$ Correspondence: migliorini.md@gmail.com

${ }^{1}$ Department of Orthopaedic, Trauma, and Reconstructive Surgery, RWTH University Hospital Aachen, Aachen, Germany

Full list of author information is available at the end of the article
}

and offer clinically meaningful feedback to patients. Arthroscopy remains the gold standard for the evaluation of the cartilage after treatment [4], but non-invasive follow-up methods are required for post-operative assessment. Plain radiography and computed tomography are inadequate for the analysis of cartilage layers, and the ionizing radiations required are of concern [5]. Magnetic resonance imaging (MRI), on the other hand, allows a detailed analysis of the cartilage and does not require ionizing radiation [6], and has thus become a widespread tool for post-operative evaluation of the outcome of OL [7]. To assess and quantify possible changes after treatment, Marlovits and colleagues introduced the Magnetic Resonance Observation of Cartilage Repair Tissue (MOCART) score [8]. However, its role in the evaluation of the treated 
cartilage and its clinical value are still debated $[1,2,9,10]$. The MOCART Score analyses different MRI variables that should correlate with the success of the operative management of OL lesions. These include degree of repair and filling of the OL, integration to border zone, surface, structure and signal intensity of the repair tissue, aspect of the subchondral lamina and bone and presence of adhesions or effusion (CIT).

The present systematic review analysed the available literature regarding the use of the MOCART score in the evaluation of osteochondral lesions of the knee and ankle. We wished to ascertain possible associations between the MOCART and other evaluation tools, which would highlight the association of the MOCART score with clinical outcomes, and support the use of this score for clinical use.

\section{Methods}

\section{Search strategy}

This systematic review was conducted according to the Preferred Reporting Items for Systematic Reviews and MetaAnalyses: the PRISMA statement [11]. The PICO framework was followed:

- P (Problem): knee and talus chondral defect;

- I (Intervention): surgical management;

- C (Control): MOCART score at last follow-up;

- O (Outcomes): clinical scores and complications.

\section{Data source}

The literature search was conducted independently by two authors $(* ; * *)$. In June 2021, the following databases were accessed: PubMed, Google scholar, Embase and Scopus with no time constrains. The following keywords were used in combination using the Boolean operators AND/OR: chondral, cartilage, articular, damage, defect, injury, chondropathy, knee, pain, matrix-induced, periosteal, periosteum, collagen, autologous, chondrocyte, transplantation, implantation, MFX, microfractures, mosaicplasty, mACI, cACI, pACI, AMIC, OAT, osteochondral transplantation, allograft, autograft, membrane, therapy, management, surgery, outcomes, revision, hypertrophy, failure. The resulting articles were screened by the same authors. The full text of the articles of interest were accessed. The bibliography of the fulltext articles was also screened. Disagreements were debated and solved by a third author $(* *)$.

\section{Eligibility criteria}

All the studies using the MOCART score for knee and/or talus chondral defects were accessed. Given the authors language abilities, articles in English, German, Italian, French and Spanish were eligible. Studies with level I-IV of evidence, according to Oxford Centre of Evidence-Based Medicine [12], were considered. Studies which reported data on patients with end-stage joint degeneration were not considered. Abstracts, reviews, comments, editorials and opinions were non considered. Animals, biomechanics or in vitro studies were not considered. Only studies which clearly stated the nature of the surgical intervention were included. Only articles reporting quantitative data under the outcomes of interest were considered for inclusion. Missing data under the outcomes of interest warranted the exclusion from this study.

\section{Data extraction}

Data extraction was performed separately by two authors $(* ; *)$. Data concerning author, year, journal, type of study and length of the follow-up was extracted. Data of the MOCART score at last follow-up was collected. The following data at baseline was collected: number of samples with related mean body mass index (BMI) and age, duration of symptoms, percentage of female, size of the defect. Data concerning the following scores at last follow-up were retrieved according to their localisation (knee and talus): visual analogue scale (VAS), American Orthopedic Foot and Ankle Score (AOFAS) [13], Tegner Activity Scale [14], Lysholm Knee Scoring Scale [15], and International Knee Documentation Committee (IKDC) [16] scores. Data on complications (rate of hypertrophy, failure and revision) were also retrieved.

\section{Methodology quality assessment}

The methodological quality assessment was performed by two independent authors $(* * ; * *)$. The risk of bias graph tool of the Review Manager Software (The Nordic Cochrane Collaboration, Copenhagen) was used. The following risk of bias were evaluated: selection, detection, attrition and other source of bias.

\section{Statistical analyses}

All statistical analyses were performed by one author (F.M.) using the software STATA/MP 14.1 (StataCorp, College Station, TX). The Shapiro-Wilk test was performed to investigate data distribution. For normal data, mean and standard deviation were calculated. For non-parametric data, median and interquartile range were calculated. The Student $t$-test was used to assess significance for parametric data, while the Mann-Whitney $U$-test for non-parametric variables. Values of $P<0.05$ considered statistically significant. A multivariate analysis was performed to assess associations between the values of the MOCART score at last follow-up and data of patients at baseline, clinical scores at last follow-up and the rate of complications. A multiple linear model regression analysis through the Pearson product-moment correlation coefficient $(r)$ was used. The Cauchy-Schwarz formula was used for inequality: +1 is considered as positive linear correlation, while -1 is considered a negative one. Values of $0.1<|r|<0.3,0.3<|r|<0.5$, and $|r|>0.5$ were considered to 
have weak, moderate and strong correlation, respectively. The overall significance was performed through the $\chi^{2}$ test, with values of $P<0.05$ considered statistically significant.

\section{Results}

Search result

The literature search identified 688 articles. Of them, 207 were duplicates. A further 481 articles were excluded as they did not match the eligibility criteria: not reporting data over the MOCART score $(N=301)$, not focusing on knee or ankle $(N=22)$, study design $(N=92)$, not reporting quantitative data under the outcomes of interest $(N=21)$, other $(N=9)$, language limitations $(N=2)$. This left 34 articles for the present study. The literature search results are shown in Fig. 1.

\section{Methodological quality assessment}

Given the limited number of randomised clinical studies (2 of 34) and the great number of retrospective studies (21 of

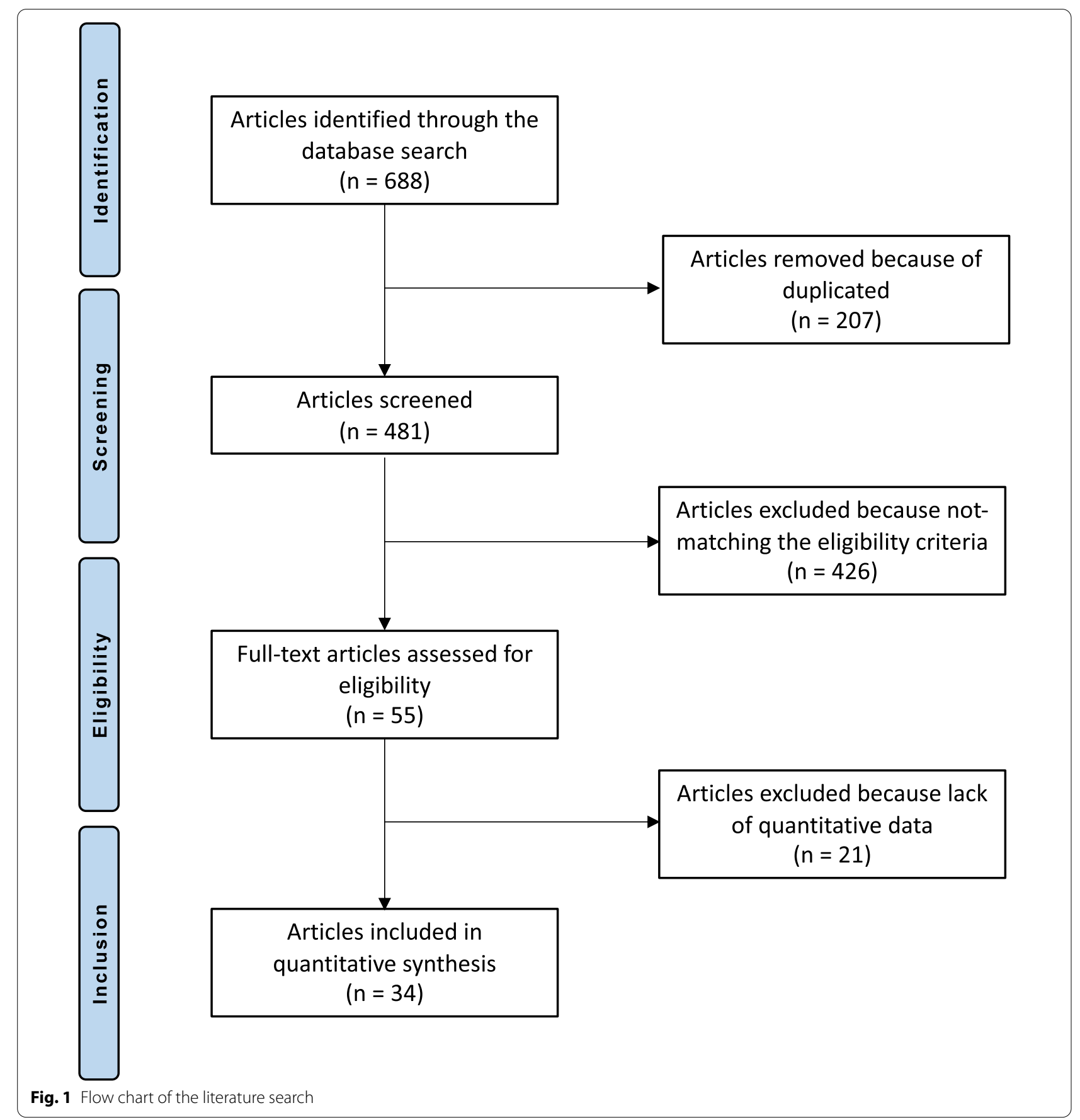


34), the risk of selection bias was moderate. The risk of detection bias was high, since most of studies lacked of blinding. The risk of attrition and reporting bias were estimated as moderate, as was the risk of other bias. In conclusion, the overall review authors' judgements about each risk of bias item scored moderate, attesting to this study fair methodological assessment. The risk of bias graph is shown in Fig. 2.

\section{Patient demographics}

Data from 1017 procedures were retrieved. The mean duration of symptoms before the index surgery was $30.1 \pm 17.7$ months. Forty percent (407 of 1017) were women. The mean age of the patients was $34.6 \pm 6.1$ years, the mean BMI was $25.7 \pm 1.7 \mathrm{~kg} / \mathrm{m}^{2}$. The mean defect size was $2.8 \pm 2 \mathrm{~cm}^{2}$. The median follow-up was 37.1 (24 to 59.9) months. Generalities and demographic of the study are presented in Table 1.

\section{Outcomes of interest}

The MOCART score at last follow-up evidenced no association with patients' age $(P=0.6)$, sex $(P=0.1)$, BMI $(P=0.06)$, defect size $(P=0.9)$ or prior length of symptoms $(P=0.9)$. For chondral defects of the knee, no association was found between the MOCART score and IKDC $(P=0.9)$, the Lysholm Knee Scoring Scale $(P=0.2)$, Tegner Activity Scale $(P=0.2)$, VAS $(P=0.07)$, rate of failure $(P=0.2)$ and revision $(P=0.9)$. For chondral defect of the talus, no significant associations were found between the MOCART score and the AOFAS $(P=0.3)$, Tegner Activity Scale $(P=0.4)$, VAS $(P=0.1)$, rate of failure $(P=0.1)$ and revision $(P=0.7)$ (Table 2).

\section{Discussion}

According to the main findings of this systematic review, the MOCART score showed no evidence of a statistically significant association with patient characteristics and surgical outcome in patients who underwent surgical management for knee and talus OL.

The MOCART score did not correlate with any of the other considered scores, namely VAS, AOFAS, IKD, Tegner and Lysholm. This finding corroborates the hypothesis that the MOCART is not a reliable tool for clinical assessment in the setting of osteochondral lesions of the knee and talus, as it does not reflect or associates to any other clinical finding. Similar results were obtained by Casari et al., who did not observe correlations between the MOCART score and other variables such as age, AOFAS score and Tegner score in patients with OL of the talus [2]. While a correlation between VAS and/or the knee injury and osteoarthritis outcome score (KOOS) and different items of the MOCART score was observed in a previous study [17], in particular 'filling the defect,' 'structure' and 'subchondral bone' [17], no evaluation of the MOCART score as a whole and VAS or KOOS was performed in that study. In addition, the overall MOCART score was not associated with the trabecular bone parameters in the injured and contralateral knee [18].

Notably, we did not observe any association between the MOCART score and the rate of failure and revision. This finding suggests that the MOCART score does not have a prognostic value in the assessment of the outcomes of surgical management of OL in the knee and talus. Also, the MOCART score did not have sufficient inter-rater reproducibility to allow reliable and univocal use in clinical practice [1].

Three modified versions of the MOCART score are presently available, namely the MOCART 2.0 [19], the modified MOCART [20] and the MOCART 3D [10]. The modified MOCART showed inhomogeneous inter-class correlation coefficients, and no strong correlation could be established between the score and the arthroscopic findings in OL of the talus [20]. The MOCART 2.0 also did not show any association with clinical parameters [2]. On the other hand, however, many items of the MOCART and

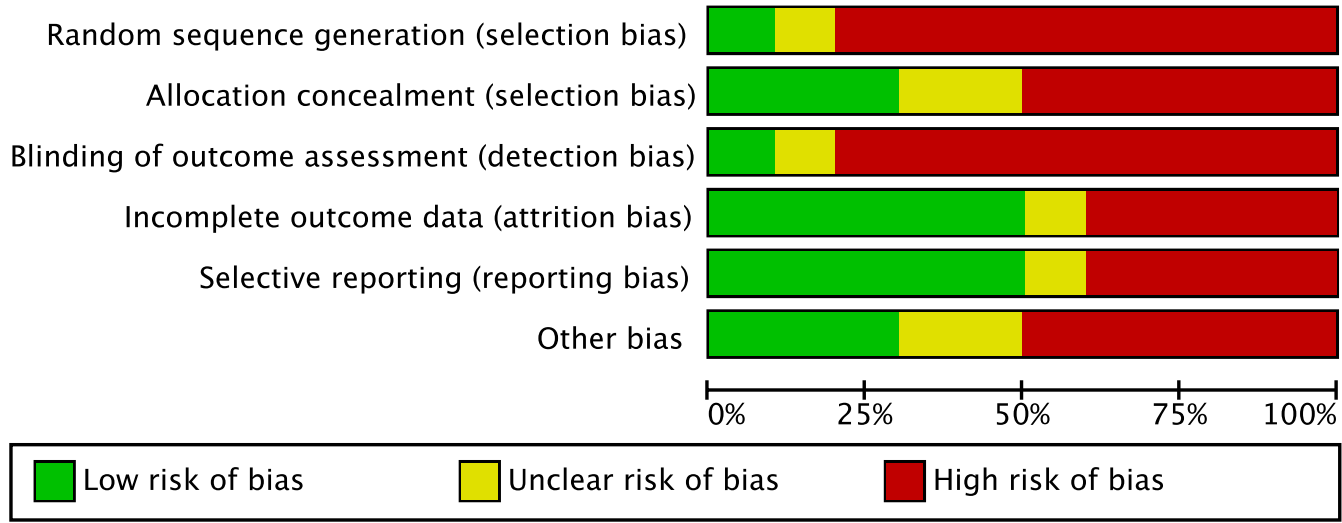

Fig. 2 Methodological quality assessment 
Table 1 Generalities and patients baseline of the included studies

\begin{tabular}{|c|c|c|c|c|c|c|c|c|}
\hline Author, year & Journal & Design & $\begin{array}{l}\text { Follow-up } \\
\text { (months) }\end{array}$ & Place & Type of treatment & Procedures $(n)$ & Female (\%) & Mean age \\
\hline $\begin{array}{l}\text { Albano et al. } 2017 \\
\text { [21] }\end{array}$ & BMC Musculos Dis & Retrospective & 30.0 & Talus & AMIC & 16 & 50.0 & 42.6 \\
\hline $\begin{array}{l}\text { Anders et al. } 2012 \\
{[22]}\end{array}$ & Int Orthop & Prospective & 63.5 & Talus & $\mathrm{MACl}$ & 22 & 22.7 & 23.9 \\
\hline \multirow{2}{*}{$\begin{array}{l}\text { Apprich et al. } 2012 \\
\text { [23] }\end{array}$} & \multirow{2}{*}{$\begin{array}{l}\text { Osteoarthritis } \\
\text { Cartilage }\end{array}$} & \multirow[t]{2}{*}{ Retrospective } & 48.0 & Talus & MACT & 10 & 60.0 & 31.0 \\
\hline & & & 59.6 & Talus & MFX & 10 & 40.0 & 32.4 \\
\hline Astur et al. 2018 [24] & Rev Bras Orthop & Prospective & 12.0 & Knee & AMIC & 7 & 14.3 & 37.2 \\
\hline $\begin{array}{l}\text { Aurich et al. } 2010 \\
\text { [25] }\end{array}$ & Am J Sports Med & Retrospective & 24.5 & Talus & $\mathrm{MACl}$ & 19 & 27.8 & 29.2 \\
\hline $\begin{array}{l}\text { Baumfeld et al. } 2018 \\
\text { [26] }\end{array}$ & Foot & Retrospective & 10.8 & Talus & AMIC & 17 & 47.1 & 37.5 \\
\hline $\begin{array}{l}\text { Becher et al. } 2015 \\
\text { [27] }\end{array}$ & $\begin{array}{l}\text { Arch Orthop Trauma } \\
\text { Surg }\end{array}$ & Prospective & 21.0 & Knee & MFX & 5 & 40.0 & 27.0 \\
\hline $\begin{array}{l}\text { DeSandis et al. } 2018 \\
\text { [28] }\end{array}$ & J Foot Ankle Surg & Retrospective & 16.7 & Talus & $\begin{array}{l}\text { Allo-transplanta- } \\
\text { tion }\end{array}$ & 46 & 54.4 & 37.6 \\
\hline $\begin{array}{l}\text { Dhollander et al. } \\
2012 \text { [29] }\end{array}$ & $\begin{array}{l}\text { Knee Surg Sports } \\
\text { Traumatol Arthrosc }\end{array}$ & Prospective & 36.0 & Knee & $\mathrm{CACl}$ & 32 & 31.0 & 30.0 \\
\hline $\begin{array}{l}\text { Di Cave et al. } 2017 \\
\text { [30] }\end{array}$ & The Foot & Retrospective & 90.0 & Talus & Scaffold & 12 & 25.0 & 38.6 \\
\hline Galla et al. 2018 [31] & $\begin{array}{l}\text { Knee Surg Sports } \\
\text { Traumatol Arthrosc }\end{array}$ & Retrospective & 33.5 & Talus & AMIC & 23 & 34.8 & 35.6 \\
\hline $\begin{array}{l}\text { Gottschalk et al. } \\
2017 \text { [32] }\end{array}$ & J Foot Ankle Surg & Retrospective & 60.0 & Talus & AMIC & 21 & 38.1 & 37.0 \\
\hline \multirow{2}{*}{$\begin{array}{l}\text { Halem et al. } 2014 \\
\text { [33] }\end{array}$} & \multirow[t]{2}{*}{ Am J Sports Med } & \multirow[t]{2}{*}{ Retrospective } & 93.0 & Talus & OAT & 14 & 50.0 & 42.8 \\
\hline & & & 85.3 & Talus & OAT & 28 & 39.3 & 44.1 \\
\hline \multirow{2}{*}{$\begin{array}{l}\text { Hoburg et al. } 2019 \\
\text { [34] }\end{array}$} & \multirow[t]{2}{*}{ Orthop J Sports Med } & \multirow[t]{2}{*}{ Prospective } & 63.0 & Knee & $\mathrm{mACl}$ & 29 & 48.0 & 16.0 \\
\hline & & & 48.0 & Knee & $\mathrm{mACl}$ & 42 & 29.0 & 27.0 \\
\hline \multirow{2}{*}{$\begin{array}{l}\text { Karnovski et al. } \\
2018 \text { [35] }\end{array}$} & \multirow[t]{2}{*}{ Foot Ankle Int } & \multirow[t]{2}{*}{ Retrospective } & 38.2 & Talus & MFX & 30 & 50.0 & 37.7 \\
\hline & & & 19.4 & Talus & $\begin{array}{l}\text { Allo- transplanta- } \\
\text { tion }\end{array}$ & 20 & 65.0 & 36.6 \\
\hline \multirow[t]{2}{*}{ Koh et al. 2016 [36] } & \multirow[t]{2}{*}{ Arthroscopy } & \multirow{2}{*}{$\begin{array}{l}\text { Prospective, Ran- } \\
\text { domised }\end{array}$} & \multirow[t]{2}{*}{27.0} & Knee & MFX & 40 & 65.0 & 38.0 \\
\hline & & & & Knee & MFX & 40 & 60.0 & 39.0 \\
\hline $\begin{array}{l}\text { Kubosch et al. } 2015 \\
\text { [9] }\end{array}$ & Int Orthop & Retrospective & 39.5 & Talus & AMIC & 17 & 47.1 & 38.8 \\
\hline $\begin{array}{l}\text { Magnan et al. } 2012 \\
{[37]}\end{array}$ & Advance Orthop & Retrospective & 45.0 & Talus & $\mathrm{MACl}$ & 30 & 50.0 & 28.9 \\
\hline $\begin{array}{l}\text { Marlovits et al. } 2012 \\
\text { [38] }\end{array}$ & Am J Sports Med & Prospective & 60.0 & Knee & $\mathrm{mACl}$ & 24 & 12.0 & 35.0 \\
\hline $\begin{array}{l}\text { Niemeyer et al. } \\
2013 \text { [39] }\end{array}$ & Am J Sports Med & Prospective & 131.0 & Knee & $\mathrm{pACl}$ & 70 & 64.0 & 33.0 \\
\hline $\begin{array}{l}\text { Ogura et al. } 2019 \\
\text { [40] }\end{array}$ & Orthop J Sports Med & Prospective & 24.0 & Knee & $\mathrm{pACl}, \mathrm{cACl}$ & 15 & 20.0 & 31.0 \\
\hline $\begin{array}{l}\text { Perdisa et al. } 2017 \\
\text { [41] }\end{array}$ & Am J Sports Med & Prospective & 24.0 & Knee & Scaffold & 34 & 47.0 & 30.0 \\
\hline $\begin{array}{l}\text { Quirbach et al. } 2009 \\
\text { [42] }\end{array}$ & Skeletal Radiol & Retrospective & 19.8 & Talus & MACT & 12 & 33.3 & 32.8 \\
\hline Rosa et al. 2015 [43] & J Orthop Traumatol & Retrospective & 148.0 & Knee & $\mathrm{pACl}$ & 15 & 40.0 & 21.0 \\
\hline $\begin{array}{l}\text { Sadlik et al. } 2017 \\
\text { [44] }\end{array}$ & Foot Ankle Surg & Retrospective & 46.4 & Talus & OAT & 10 & 40.0 & 37.0 \\
\hline \multirow{2}{*}{$\begin{array}{l}\text { Schneider et al. } \\
2016 \text { [45] }\end{array}$} & \multirow[t]{2}{*}{ J Orthop Surg } & \multirow{2}{*}{$\begin{array}{l}\text { Prospective, Ran- } \\
\text { domised }\end{array}$} & \multirow[t]{2}{*}{12.0} & Knee & MFX & 13 & 50.0 & 47.0 \\
\hline & & & & Knee & MFX & 4 & 50.0 & 37.0 \\
\hline $\begin{array}{l}\text { Schüttler et al. } 2019 \\
\text { [46] }\end{array}$ & $\begin{array}{l}\text { Arch Orthop Trauma } \\
\text { Surg }\end{array}$ & Prospective & 60.0 & Knee & $\mathrm{mACl}$ & 23 & 34.0 & \\
\hline
\end{tabular}


Table 1 (continued)

\begin{tabular}{|c|c|c|c|c|c|c|c|c|}
\hline Author, year & Journal & Design & $\begin{array}{l}\text { Follow-up } \\
\text { (months) }\end{array}$ & Place & Type of treatment & Procedures $(n)$ & Female (\%) & Mean age \\
\hline $\begin{array}{l}\text { Siebold et al. } 2018 \\
{[47]}\end{array}$ & $\begin{array}{l}\text { Knee Surg Sports } \\
\text { Traumatol Arthrosc }\end{array}$ & Prospective & 34.8 & Knee & $\mathrm{mACl}$ & 30 & 36.0 & 36.0 \\
\hline \multirow{2}{*}{$\begin{array}{l}\text { Shimozono et al. } \\
2018 \text { [48] }\end{array}$} & \multirow[t]{2}{*}{ Am J Sports Med } & \multirow[t]{2}{*}{ Retrospective } & 52.0 & Talus & OAT & 63 & 42.9 & 36.0 \\
\hline & & & 45.0 & Talus & OAT & 31 & 32.3 & 34.0 \\
\hline \multirow{2}{*}{$\begin{array}{l}\text { Shimozono et al. } \\
2018 \text { [49] }\end{array}$} & \multirow[t]{2}{*}{ Bone Joint Surg } & \multirow[t]{2}{*}{ Retrospective } & 26.3 & Talus & OAT & 25 & 64.0 & 38.4 \\
\hline & & & 22.3 & Talus & OAT & 16 & 37.5 & 43.6 \\
\hline $\begin{array}{l}\text { Usuelli et al. } 2018 \\
\text { [50] }\end{array}$ & $\begin{array}{l}\text { Knee Surg Sports } \\
\text { Traumatol Arthrosc }\end{array}$ & Retrospective & 24.0 & Talus & AMIC & 20 & 45.0 & 36.1 \\
\hline $\begin{array}{l}\text { Valderrabano et al. } \\
2013 \text { [51] }\end{array}$ & Am J Sports Med & Retrospective & 30.9 & Talus & AMIC & 26 & 30.8 & 34.6 \\
\hline $\begin{array}{l}\text { Weigelt et al. } 2019 \\
\text { [52] }\end{array}$ & Am J Sports Med & Retrospective & 56.4 & Talus & AMIC & 33 & 4.2 & 35.1 \\
\hline $\begin{array}{l}\text { Wiewiorski et al. } \\
2013 \text { [53] }\end{array}$ & Clin Radiology & Retrospective & 23.3 & Talus & AMIC & 23 & 30.4 & 34.2 \\
\hline
\end{tabular}

Table 2 Overall results of the analyses

\begin{tabular}{lrl}
\hline Endpoint & \multicolumn{1}{l}{$\boldsymbol{r}$} & $\boldsymbol{P}$ \\
\hline Patient characteristics & -0.22 & \\
Sex & 0.08 & 0.1 \\
Mean age & -0.54 & 0.6 \\
BMI & -0.02 & 0.06 \\
Defect size (cm $\left.{ }^{2}\right)$ & -0.01 & 0.9 \\
Prior symptoms (months) & & 0.9 \\
Knee chondral defects & -0.45 & \\
VAS & -0.55 & 0.07 \\
Tegner & -0.71 & 0.2 \\
Lysholm & 0.00 & 0.2 \\
IKD & -0.30 & 0.9 \\
Rate of failure & 0.01 & 0.2 \\
Rate of revision & & 0.9 \\
Talus chondral defects & -0.33 & \\
VAS & -0.24 & 0.1 \\
Tegner & 0.29 & 0.4 \\
AOFAS & -0.44 & 0.3 \\
Rate of failure & 0.10 & 0.1 \\
Rate of revision & & 0.7 \\
\hline
\end{tabular}

MOCART 3D showed good correlations with histological scoring systems [10]. Given these limitations, it is difficult to interpret the lack of relationship between age, sex, BMI and defect size and the MOCART score. One possible key is that the MOCART score is not influenced by these factors, or that age, sex and BMI do not influence the extent of OL lesions. The available data do not allow clarification of this issue.

Overall, the question arises whether MRI is a reliable enough tool to assess chondral damage and to follow-up OL treatment, or whether the MOCART score is not a powerful enough tool to allow association of imaging and clinical data. Numerous studies support the use of MRI when following patients with OL of the knee and of the talus. MRI changes of the chondral surface correlate with the structure of the underlying trabecular bone [18], and the combination of clinical parameters with specific MR imaging acquisition represents a promising tool in the follow-up of OL treatment $[4,10]$. These findings, combined with the findings of a present study, support the hypothesis that the MOCART score, more than the MRI itself, is not a reliable tool in the follow-up of patients who underwent surgical treatment of OL lesions. However, strong evidence supporting the use of MRI as gold standard in the assessment of OL and its treatment is still lacking [7].

This study does not come without limitations. First, only the evaluation of the MOCART score and not of its successive implementation was possible given the lack of data available for the analysis. Although several studies focused on the management of chondral defects of the knee and talus, relevant quantitative data available for inclusion and analysis were limited. The lack of RCTs also represent an inevitable bias in the interpretation of the results.

\section{Conclusion}

The MOCART score demonstrated no association with patient characteristics and surgical outcome in patients who underwent surgical management for chondral defects of the knee and talus.

\section{Abbreviations}

MOCART: Magnetic Resonance Observation of Cartilage Repair Tissue; VAS: Visual analogue scale; OL: Osteochondral lesions; MRl: Magnetic resonance imaging; PRISMA: Preferred Reporting Items for Systematic Reviews and Meta-Analyses; 
AOFAS: American Orthopedic Foot and Ankle Score; IKDC: International Knee Documentation Committee; BMl: Body mass index.

\section{Acknowledgements}

None.

\section{Authors' contributions}

F.M.: conception and design of the study, literature search, data extraction, methodological quality assessment, writing, analysis, interpretation of data and final approval; A.B.: literature search, data extraction, methodological quality assessment, writing and final approval; N.M.: revision and final approval; J.E., M.T.: supervision and final approval. All authors read and approved the final manuscript.

\section{Funding}

Open Access funding enabled and organized by Projekt DEAL. No external source of funding was used.

\section{Availability of data and materials}

The data underlying this article are available in the article and in its online supplementary material.

\section{Declarations}

\section{Ethics approval consent to participate}

Not applicable.

\section{Consent for publication}

Not applicable.

\section{Competing interests}

The authors declare that they have no conflict of interest.

\section{Author details}

'Department of Orthopaedic, Trauma, and Reconstructive Surgery, RWTH University Hospital Aachen, Aachen, Germany. ${ }^{2}$ Department of Medicine, Surgery and Dentistry, University of Salerno, Via S. Allende, 84081 Baronissi, SA, Italy. ${ }^{3}$ School of Pharmacy and Bioengineering, Keele University School of Medicine, Thornburrow Drive, Stoke on Trent, England, UK. ${ }^{4}$ Queen Mary University of London, Barts and the London School of Medicine and Dentistry, Centre for Sports and Exercise Medicine, Mile End Hospital, 275 Bancroft Road, London E1 4DG, England, UK.

\section{Received: 10 March 2021 Accepted: 26 September 2021}

Published online: 06 October 2021

\section{References}

1. Albano D, Martinelli N, Bianchi A, Giacalone A, Sconfienza LM (2017) Evaluation of reproducibility of the MOCART score in patients with osteochondral lesions of the talus repaired using the autologous matrix-induced chondrogenesis technique. Radiol Med 122:909-917

2. Casari FA, Germann C, Weigelt L, Wirth S, Viehofer A, Ackermann J. The role of magnetic resonance imaging in autologous matrix-induced chondrogenesis for osteochondral lesions of the talus: analyzing MOCART 1 and 2.0. Cartilage 2020: 1947603520946382.

3. van Dijk CN, Reilingh ML, Zengerink M, van Bergen CJ (2010) Osteochondral defects in the ankle: why painful? Knee Surg Sports Traumatol Arthrosc 18:570-580

4. Liu YW, Tran MD, Skalski MR, Patel DB, White EA, Tomasian A et al (2019) MR imaging of cartilage repair surgery of the knee. Clin Imaging 58:129-139

5. Schuman L, Struijs PA, van Dijk CN (2002) Arthroscopic treatment for osteochondral defects of the talus. Results at follow-up at 2 to 11 years. J Bone Joint Surg Br. 84:364-368

6. Recht M, White LM, Winalski CS, Miniaci A, Minas T, Parker RD (2003) MR imaging of cartilage repair procedures. Skeletal Radiol 32:185-200

7. de Windt TS, Welsch GH, Brittberg M, Vonk LA, Marlovits S, Trattnig S et al (2013) Is magnetic resonance imaging reliable in predicting clinical outcome after articular cartilage repair of the knee? A systematic review and metaanalysis. Am J Sports Med 41:1695-1702
8. Marlovits S, Striessnig G, Resinger CT, Aldrian SM, Vecsei V, Imhof H et al (2004) Definition of pertinent parameters for the evaluation of articular cartilage repair tissue with high-resolution magnetic resonance imaging. Eur J Radiol 52:310-319

9. Kubosch EJ, Erdle B, Izadpanah K, Kubosch D, Uhl M, Sudkamp NP et al (2016) Clinical outcome and $\mathrm{T} 2$ assessment following autologous matrix-induced chondrogenesis in osteochondral lesions of the talus. Int Orthop 40:65-71

10. Goebel L, Zurakowski D, Muller A, Pape D, Cucchiarini M, Madry H (2014) 2D and 3D MOCART scoring systems assessed by 9.4T high-field MRI correlate with elementary and complex histological scoring systems in a translational model of osteochondral repair. Osteoarthr Cartil 22:1386-1395

11. Moher D, Liberati A, Tetzlaff J, Altman DG, Group P. Preferred reporting items for systematic reviews and meta-analyses: the PRISMA statement. BMJ 2009; 339: b2535.

12. Howick J Cl, Glasziou P, Greenhalgh T, Carl Heneghan, Liberati A, Moschetti I, Phillips B, Thornton H, Goddard O, Hodgkinson M. The 2011 Oxford CEBM Levels of Evidence. Oxford Centre for Evidence-Based Medicine. https://www. cebm.net/index.aspx?o=5653 2011.

13. Kitaoka HB, Alexander IJ, Adelaar RS, Nunley JA, Myerson MS, Sanders M (1994) Clinical rating systems for the ankle-hindfoot, midfoot, hallux, and lesser toes. Foot Ankle Int 15:349-353

14. Briggs KK, Lysholm J, Tegner Y, Rodkey WG, Kocher MS, Steadman JR (2009) The reliability, validity, and responsiveness of the Lysholm score and Tegner activity scale for anterior cruciate ligament injuries of the knee: 25 years later. Am J Sports Med 37:890-897

15. Lysholm J, Gillquist J (1982) Evaluation of knee ligament surgery results with special emphasis on use of a scoring scale. Am J Sports Med 10:150-154

16. Higgins LD, Taylor MK, Park D, Ghodadra N, Marchant M, Pietrobon R et al (2007) Reliability and validity of the International Knee Documentation Committee (IKDC) Subjective Knee Form. Joint Bone Spine 74:594-599

17. Marlovits S, Singer P, Zeller P, Mandl I, Haller J, Trattnig S (2006) Magnetic resonance observation of cartilage repair tissue (MOCART) for the evaluation of autologous chondrocyte transplantation: determination of interobserver variability and correlation to clinical outcome after 2 years. Eur J Radiol 57:16-23

18. Gersing AS, Feuerriegel G, Holwein C, Suchowierski J, Karampinos DC, Haller B et al (2019) T2-relaxation time of cartilage repair tissue is associated with bone remodeling after spongiosa-augmented matrix-associated autologous chondrocyte implantation. Osteoarthr Cartil 27:90-98

19. Schreiner MM, Raudner M, Marlovits S, Bohndorf K, Weber M, Zalaudek M et al. The MOCART (Magnetic Resonance Observation of Cartilage Repair Tissue) 2.0 Knee Score and Atlas. Cartilage 2019: 1947603519865308.

20. Lee KT, Choi YS, Lee YK, Cha SD, Koo HM (2011) Comparison of MRI and arthroscopy in modified MOCART scoring system after autologous chondrocyte implantation for osteochondral lesion of the talus. Orthopedics 34:e356-362

21. Albano D, Martinelli N, Bianchi A, Messina C, Malerba F, Sconfienza LM (2017) Clinical and imaging outcome of osteochondral lesions of the talus treated using autologous matrix-induced chondrogenesis technique with a biomimetic scaffold. BMC Musculoskelet Disord 18:306

22. Anders S, Goetz J, Schubert T, Grifka J, Schaumburger J (2012) Treatment of deep articular talus lesions by matrix associated autologous chondrocyte implantation-results at five years. Int Orthop 36:2279-2285

23. Apprich S, Trattnig S, Welsch GH, Noebauer-Huhmann IM, Sokolowski M, Hirschfeld C et al (2012) Assessment of articular cartilage repair tissue after matrix-associated autologous chondrocyte transplantation or the microfracture technique in the ankle joint using diffusion-weighted imaging at 3 Tesla. Osteoarthr Cartil 20:703-711

24. Astur DC, Lopes JC, Santos MA, Kaleka CC, Amaro JT, Cohen M (2018) Surgical treatment of chondral knee defects using a collagen membrane-autologus matrix-induced chondrogenesis. Rev Bras Ortop 53:733-739

25. Aurich M, Bedi HS, Smith PJ, Rolauffs B, Muckley T, Clayton J et al (2011) Arthroscopic treatment of osteochondral lesions of the ankle with matrix-associated chondrocyte implantation: early clinical and magnetic resonance imaging results. Am J Sports Med 39:311-319

26. Baumfeld T, Baumfeld D, Prado M, Nery C (2018) All-arthroscopic AMIC((R)) (AT-AMIC) for the treatment of talar osteochondral defects: a short followup case series. Foot 37:23-27

27. Becher C, Ettinger M, Ezechieli M, Kaps C, Ewig M, Smith T (2015) Repair of retropatellar cartilage defects in the knee with microfracture and a cell-free polymer-based implant. Arch Orthop Trauma Surg 135:1003-1010 
28. DeSandis BA, Haleem AM, Sofka CM, O'Malley MJ, Drakos MC (2018) Arthroscopic treatment of osteochondral lesions of the talus using juvenile articular cartilage allograft and autologous bone marrow aspirate concentration. J Foot Ankle Surg 57:273-280

29. Dhollander AA, Verdonk PC, Lambrecht S, Verdonk R, Elewaut D, Verbruggen $\mathrm{G}$ et al (2012) Short-term outcome of the second generation characterized chondrocyte implantation for the treatment of cartilage lesions in the knee. Knee Surg Sports Traumatol Arthrosc 20:1118-1127

30. Di Cave E, Versari P, Sciarretta F, Luzon D, Marcellini L (2017) Biphasic bioresorbable scaffold (TruFit Plug((R))) for the treatment of osteochondral lesions of talus: 6- to 8-year follow-up. Foot 33:48-52

31. Galla M, Duensing I, Kahn TL, Barg A (2019) Open reconstruction with autologous spongiosa grafts and matrix-induced chondrogenesis for osteochondral lesions of the talus can be performed without medial malleolar osteotomy. Knee Surg Sports Traumatol Arthrosc 27:2789-2795

32. Gottschalk O, Altenberger S, Baumbach S, Kriegelstein S, Dreyer F, Mehlhorn A et al (2017) Functional medium-term results after autologous matrixinduced chondrogenesis for osteochondral lesions of the talus: a 5-year prospective cohort study. J Foot Ankle Surg 56:930-936

33. Haleem AM, Ross KA, Smyth NA, Duke GL, Deyer TW, Do HT et al (2014) Double-plug autologous osteochondral transplantation shows equal functional outcomes compared with single-plug procedures in lesions of the talar dome: a minimum 5-year clinical follow-up. Am J Sports Med 42:1888-1895

34. Hoburg A, Loer I, Korsmeier K, Siebold R, Niemeyer P, Fickert S et al (2019) Matrix-associated autologous chondrocyte implantation is an effective treatment at midterm follow-up in adolescents and young adults. Orthop J Sports Med 7:2325967119841077

35. Karnovsky SC, DeSandis B, Haleem AM, Sofka CM, O'Malley M, Drakos MC (2018) Comparison of juvenile allogenous articular cartilage and bone marrow aspirate concentrate versus microfracture with and without bone marrow aspirate concentrate in arthroscopic treatment of talar osteochondral lesions. Foot Ankle Int 39:393-405

36. Koh YG, Kwon OR, Kim YS, Choi YJ, Tak DH (2016) Adipose-derived mesenchymal stem cells with microfracture versus microfracture alone: 2-year follow-up of a prospective randomized trial. Arthroscopy 32:97-109

37. Magnan B, Samaila E, Bondi M, Vecchini E, Micheloni GM, Bartolozzi P (2012) Three-dimensional matrix-induced autologous chondrocytes implantation for osteochondral lesions of the talus: midterm results. Adv Orthop 2012:942174

38. Marlovits S, Aldrian S, Wondrasch B, Zak L, Albrecht C, Welsch G et al (2012) Clinical and radiological outcomes 5 years after matrix-induced autologous chondrocyte implantation in patients with symptomatic, traumatic chondral defects. Am J Sports Med 40:2273-2280

39. Niemeyer P, Porichis S, Steinwachs M, Erggelet C, Kreuz PC, Schmal H et al (2014) Long-term outcomes after first-generation autologous chondrocyte implantation for cartilage defects of the knee. Am J Sports Med 42:150-157

40. Ogura T, Merkely G, Bryant T, Winalski CS, Minas T (2019) Autologous chondrocyte implantation "segmental-sandwich" technique for deep osteochondral defects in the knee: clinical outcomes and correlation with magnetic resonance imaging findings. Orthop J Sports Med 7:2325967119847173

41. Perdisa F, Filardo G, Sessa A, Busacca M, Zaffagnini S, Marcacci M et al (2017) One-step treatment for patellar cartilage defects with a cell-free osteochondral scaffold: a prospective clinical and MRI evaluation. Am J Sports Med 45:1581-1588

42. Quirbach S, Trattnig S, Marlovits S, Zimmermann V, Domayer S, Dorotka $R$ et al (2009) Initial results of in vivo high-resolution morphological and biochemical cartilage imaging of patients after matrix-associated autologous chondrocyte transplantation (MACT) of the ankle. Skeletal Radiol 38:751-760
43. Rosa D, Balato G, Ciaramella G, Soscia E, Improta G, Triassi M (2016) Longterm clinical results and MRI changes after autologous chondrocyte implantation in the knee of young and active middle aged patients. J Orthop Traumatol 17:55-62

44. Sadlik B, Kolodziej L, Blasiak A, Szymczak M, Warchal B (2017) Biological reconstruction of large osteochondral lesions of the talar dome with a modified "sandwich" technique-midterm results. Foot Ankle Surg 23:290-295

45. Schneider U (2016) Controlled, randomized multicenter study to compare compatibility and safety of ChondroFiller liquid (cell free 2-component collagen gel) with microfracturing of patients with focal cartilage defects of the knee joint. J Ortop Surg 1:1-8

46. Schuttler KF, Gotschenberg A, Klasan A, Stein T, Pehl A, Roessler PP et al (2019) Cell-free cartilage repair in large defects of the knee: increased failure rate 5 years after implantation of a collagen type I scaffold. Arch Orthop Trauma Surg 139:99-106

47. Siebold R, Suezer F, Schmitt B, Trattnig S, Essig M (2018) Good clinical and MRI outcome after arthroscopic autologous chondrocyte implantation for cartilage repair in the knee. Knee Surg Sports Traumatol Arthrosc 26:831-839

48. Shimozono Y, Donders JCE, Yasui Y, Hurley ET, Deyer TW, Nguyen JT et al (2018) Effect of the containment type on clinical outcomes in osteochondral lesions of the talus treated with autologous osteochondral transplantation. Am J Sports Med 46:2096-2102

49. Shimozono Y, Hurley ET, Nguyen JT, Deyer TW, Kennedy JG (2018) Allograft compared with autograft in osteochondral transplantation for the treatment of osteochondral lesions of the talus. J Bone Joint Surg Am 100:1838-1844

50. Usuelli FG, D'Ambrosi R, Maccario C, Boga M, de Girolamo L (2018) Allarthroscopic AMIC((R)) (AT-AMIC((R))) technique with autologous bone graft for talar osteochondral defects: clinical and radiological results. Knee Surg Sports Traumatol Arthrosc 26:875-881

51. Valderrabano V, Miska M, Leumann A, Wiewiorski M (2013) Reconstruction of osteochondral lesions of the talus with autologous spongiosa grafts and autologous matrix-induced chondrogenesis. Am J Sports Med 41:519-527

52. Weigelt L, Hartmann R, Pfirrmann C, Espinosa N, Wirth SH (2019) Autologous matrix-induced chondrogenesis for osteochondral lesions of the talus: a clinical and radiological 2- to 8-year follow-up study. Am J Sports Med 47:1679-1686

53. Wiewiorski M, Miska M, Kretzschmar M, Studler U, Bieri O, Valderrabano V (2013) Delayed gadolinium-enhanced MRI of cartilage of the ankle joint: results after autologous matrix-induced chondrogenesis (AMIC)aided reconstruction of osteochondral lesions of the talus. Clin Radiol 68:1031-1038

\section{Publisher's Note}

Springer Nature remains neutral with regard to jurisdictional claims in published maps and institutional affiliations.

\section{Submit your manuscript to a SpringerOpen ${ }^{\circ}$ journal and benefit from:}

- Convenient online submission

- Rigorous peer review

- Open access: articles freely available online

- High visibility within the field

- Retaining the copyright to your article

Submit your next manuscript at $\boldsymbol{\Delta}$ springeropen.com 